Sains Malaysiana 49(7)(2020): 1521-1531

http://dx.doi.org/10.17576/jsm-2020-4907-05

\title{
Mechanical Properties Experiment of Load Capacity on a Mechanical Yielding Steel Prop (MYSP) and Its Application in Roadway Support
}

(Uji Kaji Sifat Mekanik Kapasiti Beban ke atas Prop Keluli Hasil Mekanik (MYSP) dan Aplikasinya dalam Sokongan Jalan Raya)

\author{
Yanlong Chen, Hai Pu, Peng Wu*, Haoshuai Wu, Yu Wu, Yang HaO, Goh Thian Lai, Azrin Azmi \& \\ MUSLIM ABDURRAHMAN
}

\begin{abstract}
As the coal mining depth increases year by year, the deformation and failure of deep roadway become more serious. Therefore, new support equipment with high supporting force and yieldable character is quite necessary for mining safety. In this research, a new mechanical yielding steel prop (MYSP) with high stable load capacity was introduced, which features sustaining large deformation in the field. The test shows that the load capacity provided by doublelayer steel balls is greater than that of single-layer steel balls, and that provided by high-hardness steel balls is higher than that of low-hardness steel balls. When double-layer high-hardness steel balls are adopted, the load capacity firstly increases and then remains stable with the increase of displacement, while it firstly increases and then decreases and finally remains stable with the increase of displacement when double-layer low-hardness steel balls are adopted. The load capacity decreases with the increase of inclined angle of the outer tube, but the influence of the inclined angle of the outer tube on load capacity provided by high-hardness steel balls is small. The load capacity increases gradually with the yielding strength of the prop. Therefore, the MYSP with different load capacities can be designed by changing the yielding strength of the outer tube and inner tube. The field application shows that the MYSP has good characteristics of yielding and high constant resistance. It is very effective for controlling the deformation of surrounding rock mass using the MYSP for roadway pre-support, which also reduces the supporting cost significantly.
\end{abstract}

Keywords: Experiment; load capacity; mechanical properties; mechanical yielding; roadway support; steel prop

ABSTRAK

Apabila kedalaman perlombongan arang batu meningkat tahun demi tahun, kecanggaan dan kegagalan jalan dalam menjadi lebih serius. Oleh itu, peralatan sokongan baru yang mempunyai ciri-ciri daya sokongan yang tinggi adalah sangat diperlukan untuk keselamatan perlombongan. Dalam penyelidikan ini, sebuah penyokong keluli mekanikal yang baru (MYSP) dengan kestabilan keupayaan beban yang tinggi telah diperkenalkan, berciri menahan kecanggaan besar di lapangan. Ujian ini menunjukkan bahawa keupayaan beban yang dihasilkan oleh bebola keluli dua-lapisan adalah lebih besar daripada bebola keluli satu-lapisan dan bebola keluli kekerasan-tinggi adalah lebih tinggi daripada bebola keluli kekerasan-rendah. Apabila bebola keluli dua-lapisan kekerasan-tinggi digunakan, pada permulaannya, keupayaan beban meningkat dan kemudian tidak berubah dengan kenaikan alihan, sementara ia bertambah pada awal dan kemudian berkurangan dan akhirnya kekal tidak berubah dengan kenaikan alihan apabila bebola keluli dua lapisan kekerasan-rendah digunakan. Keupayaan beban berkurangan dengan peningkatan sudut kemiringan silinder, tetapi pengaruh sudut kemiringan silinder pada keupayaan beban yang dihasilkan oleh bebola keluli kekerasan-tinggi adalah rendah. Keupayaan beban meningkat secara beransur-ansur dengan nilai kekuatan penyokong. Oleh itu, MYSP dengan keupayaan beban yang berbeza dapat direka bentuk dengan mengubah nilai kekuatan silinder dan kutub. Aplikasi lapangan menunjukkan bahawa MYSP mempunyai ciri-ciri yang baik dan daya rintangan berterusan yang tinggi. Ia sangat berkesan untuk mengawal kecanggaan batuan di sekeliling dengan menggunakan MYSP sebagai prasokongan jalan raya, justeru mengurangkan kos sokongan dengan ketara.

Kata kunci: Keupayaan beban; penyokong keluli mekanikal; sifat mekanik; sokongan jalan raya; ujian

\section{INTRODUCTION}

Due to the large-scale exploitation in recent years, shallow coal resources gradually decrease and the mining depth increases year by year (Chen et al. 2017; Hao et al. 2018).
Currently, some mining areas have entered into a state of deep mining (Chen et al. 2018; Kang 2014; Yang et al. 2019, 2017). Due to the mining influence on roadway in deep mining created many challenging issues, such as 
large deformation of surrounding rock mass (Chen et al. 2019), difficulties in providing sufficient support and high repair rates, are particularly prominent (Chen et al. 2016; Tang et al. 2018; Wang et al. 2018, 2016; Zuo et al. 2018). Basically, the mining roadway is built within the coal seam, close to the disturbance source, where the strength of surrounding rock is relatively low and influenced intensely by mining. If the support is not designed efficiently, it may affect the safety and production of the coal mine (Wu et al. 2018; Zhang et al. 2019).

Many scholars carried out a large number of experimental studies on support of deep mining roadway (Peng et al. 2018; Qin et al. 2019; Wang et al. 2017; Zhang et al. 2019). The support manner is mainly divided into two types: One is called the active flexible support with anchors bolts (cables); another is the passive rigid support with hydraulic single prop. The first type of support type is more economical and easy to be installed. It can control well the full upper part of surrounding rock of roadway by applying pre-loaded force. However, due to the serious breakage and large deformation of surrounding rock in roadway, the bolt and cable cannot exert the ultimate anchorage strength, which leads to poor anchorage effect and is unable to provide sufficient support. Basically, the load capacity of the second support type can reach up to $200 \sim 300 \mathrm{kN}$. However, this kind of support equipment has no yielding space, which is unable adapt to large deformation of surrounding rock, and lead to unloading failure easily under high ground stress conditions in deep roadway.

In order to overcome large deformation of surrounding rock in deep mining roadway, a new type of support structure needs to be developed (Chen et al. 2017; Hao et al. 2018). This paper introduces an innovative single prop, named the mechanical yielding steel prop (MYSP). Its load capacity is very large, generally up to 400 500 $\mathrm{kN}$, and can reach more than $1000 \mathrm{kN}$ by changing its materials and structural parameters. Usually, the maximum constant resistance falling distance can reach to $40 \%$ of the support height of the MYSP. Actually, the MYSP is completely different from the friction metal prop (FMP) and the hydraulic single prop (HSP). The FMP (Qin 1995) utilized the friction between the metal pin and the pole to provide the load capacity. The load capacity depends on the inclined angle of wedge with the friction disc. This angle is affected by the installation operation and specific working conditions. Therefore, the safety and stability of FMP is not reliable- The HSP (GonzálezNicieza et al. 2008; Wang et al. 2013; Zhang et al. 2015) is depending on the high pressure liquid sealed in cylinder block where it provides load capacity support to the pole. However, it fails to maximize the mechanical strength of the cylinder and the pole. It also creates high pressure sealing issues at pole and the supply pump station. However, the load capacity of the MYSP generated by pressurized the contact surface between the pole and the steel balls. The load capacity depends on the material properties of the steel balls and the pole itself, which is not affected by the installation, environment and any other external factors. In this paper, a large number of laboratory tests were carried out to determine optimum load capacity of the MYSP by investigating the impact of structural parameters to deformation. It is proved that MYSP is potentially to apply in coal mining roadway with large deformation.

\section{MATERIALS AND METHODS}

\section{STRUCTURAL CHARACTERISTICS AND WORKING PRINCIPLE OF THE MYSP}

The MYSP consists of an outer tube, an inner tube and lots of steel balls (Figure 1(a)). The steel balls are located between the outer wall of the inner tube and the inner wall of the outer tube.

When the MYSP suffers from an increased load, the strained condition of the outer and inner tubes can be divided into four stages, as displayed in Figure 1(b) (Chen et al. 2017). Firstly, the prop does not suffer from the loading, and the prop is under the equilibrium state. Secondly, the inner tube is loaded gradually, the contact areas between the steel balls with the outer and inner tubes behave elastically. With the load increasing, the plastic deformation begins to occur at the contact areas. Thirdly, as the continued increase of the embedded depth of the steel ball, the load capacity of the prop is also increased. Finally, the prop reaches the stable load capacity and the inner tube moves downwards continuously.

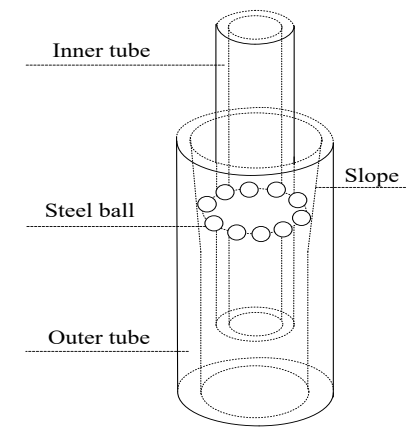

(a) 


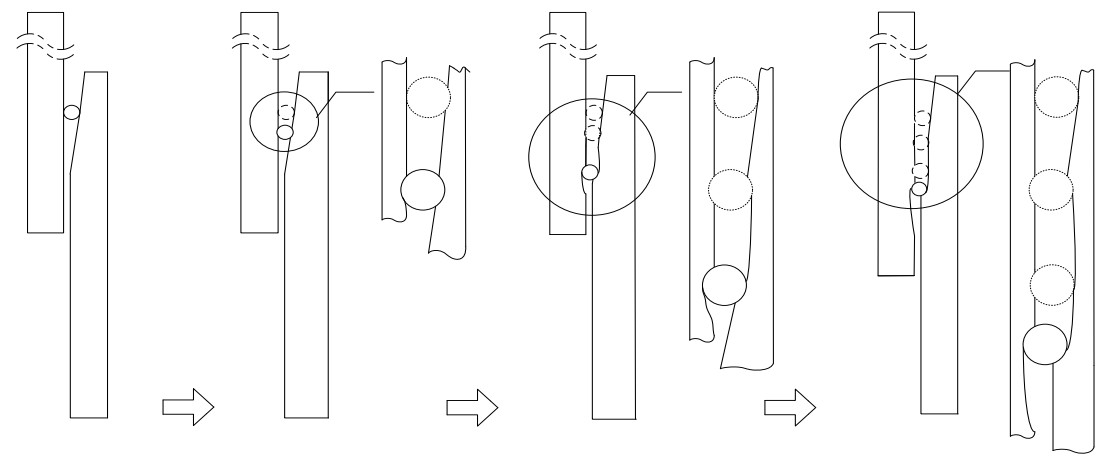

(b)

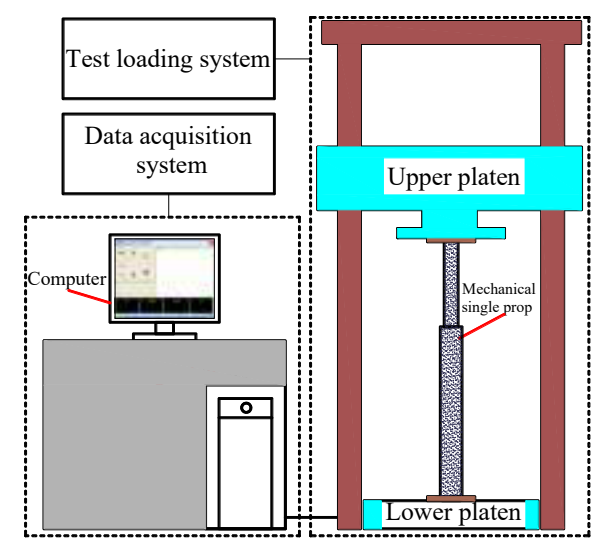

(c)

FIGURE 1. (a) 3-D structure diagram of the MYSP; (b) Deformation stage of the MYSP; (c) Schematic diagram of the NSY500 testing system

\section{EXPERIMENTAL DETAILS}

The mechanical experiment was conducted in the State Key Laboratory for Geomechanics and Deep Underground Engineering, China University of Mining and Technology by using NSY500. The NSY500 testing system (Figure 1(c)) comprised the loading test system and data acquisition system. The main parts of the loading test system are the upper pressure board and the lower pressure board. The upper pressure board is nonadjustable and the down pressure board able to be adjusted upward to produce load capacity for the test. The loading height of the specimen ranges from $0 \sim 4000 \mathrm{~mm}$ and the loading displacement ranges from $0 \sim 500 \mathrm{~mm}$. The axial load capacity ranges from $0 \sim 5000 \mathrm{kN}$ with the test force error of $\pm 1 \%$. The data acquisition system is used to monitor, control real time test loading system and record the real-time date.

\section{METHODS}

The main purpose of this test was to determine the optimization of the mechanical properties of load capacity for MYSP. Factors affect the load capacity are the mediums (the steel discs and steel balls), diameters, the layer number and the materials of steel balls, the inclined angle of the outer tube, and the materials of the outer tube and inner tube. Therefore, four groups of experimental schemes were designed for different influencing factors and the loading rate was $0.5 \mathrm{kN} / \mathrm{s}$ on force loading.

The first scheme: The steel discs between the outer tube and inner tube act as the friction mediums and the influences of the quantity and length of steel discs and the inclined angle of the outer tube on load capacity were analyzed. The inclined angle on the upper end surface of the outer tuber was set to zero, the respective length of steel discs was 10,20 , and $30 \mathrm{~mm}$ and the quantity of steel discs is 6 and 19. No inclined angle on the upper end surface of the outer tube, and the length of steel discs is 10,20 , and $30 \mathrm{~mm}$, respectively, and the quantity of steel discs is 6 and 19, respectively. No inclined angle, small inclined angle and large inclined angle on the upper end surface of the outer tube, respectively, and nineteen $20 \mathrm{~mm}$ long steel discs are used. 
The second scheme: The low-hardness steel balls between the outer tube and inner tube act as the mediums, and the influence of the diameters and number layer of steel balls on load capacity were analyzed. The inclined angle of the outer tube $\theta$ is $5.71^{\circ}$, and the diameter of low-hardness steel balls $D_{1}$ is $4.00,4.40$ and $4.83 \mathrm{~mm}$, respectively.

The third scheme: The low-hardness steel balls and high-hardness steel balls between the outer tube and inner tube act as the mediums, and the influence of the materials of steel balls and the inclined angle of the outer tube on load capacity were analyzed. For the double-layer steel balls with low-hardness, the diameter of the steel balls $D_{1}$ is $4.40 \mathrm{~mm}$, and the inclined angle of the outer tube $\theta$ is $3.81,4.57,5.71$ and $7.13^{\circ}$, respectively; For the double-layer steel balls with high-hardness, the diameter of the steel balls $D_{2}$ is $4.40 \mathrm{~mm}$, and the inclined angle of the outer tube $\theta$ is $3.81,4.57,5.71$ and $7.13^{\circ}$, respectively.

The fourth scheme: The high-hardness steel balls between the outer tube and inner tube act as the mediums, and the influence of yielding strength of MYSP on load capacity was analyzed. For the double-layer steel balls, the diameter $D_{2}$ is $4.40 \mathrm{~mm}$, and the inclined angle of the outer tube $\theta$ is $5.71^{\circ}$. The yielding strength of MYSP is $235,345,690$ and $835 \mathrm{MPa}$, respectively.

\section{RESULTS AND DISCUSSION}

\section{LOAD CAPACITY ANALYSIS WHEN THE STEEL DISCS ARE USED AS THE FRICTION MEDIUMS}

At the beginning of the test, load capacity analysis was carried out with steel discs, and the position of steel discs was set same level with steel balls. Figure 2 shows the load capacity-displacement curves of different sizes and quantities of steel discs and different inclined angles of the outer tube. Under the conditions of 6 pieces of steel discs and $0^{\circ}$ of inclined angle of the outer tube, with the length of steel discs were 10,20 , and $30 \mathrm{~mm}$, the test showed that the maximum load capacities are 3.8, 3.1, and $6.4 \mathrm{kN}$ (Figure 2(a)) and the stable load capacities are $2.9,2.5$ and $5.8 \mathrm{kN}$, respectively. The curves also showed that with the increase of the length of steel discs, the maximum load capacity decreases at the beginning and then increases, and the stable load capacity increases at the beginning and then decreases.

The maximum load capacities are 13,15 , and 10 $\mathrm{kN}$, and the stable load capacity is $9.5,11.9$, and $5.3 \mathrm{kN}$, respectively, under the condition of 19 pieces of steel discs. The maximum load capacity increases by 242 , 384 , and $56 \%$ (Figure 2(b)), and the stable load capacity increases by 228,376 , and $-9 \%$, respectively, when compared to the results under six piece of steel discs. Therefore, the length of steel discs as $20 \mathrm{~mm}$ under the consideration of the placement of 19 pieces of steel discs was selected as the optimum performance of prop.

It can be found that the inclined angle of the outer tube has obvious influence on the load capacitydisplacement curve of steel discs. The maximum load capacity for zero inclined angle, small inclined angle to large inclined angle are $15.0,23.0$, and $65.0 \mathrm{kN}$, respectively. Besides, the respective stable load capacity for zero inclined angle, small inclined angle to large inclined angle are 9.5, 16.5, and $45.0 \mathrm{kN}$. Therefore, it is very effective to increase the load capacity by increasing the inclined angle of the outer tube for $20 \mathrm{~mm}$ length of steel discs.

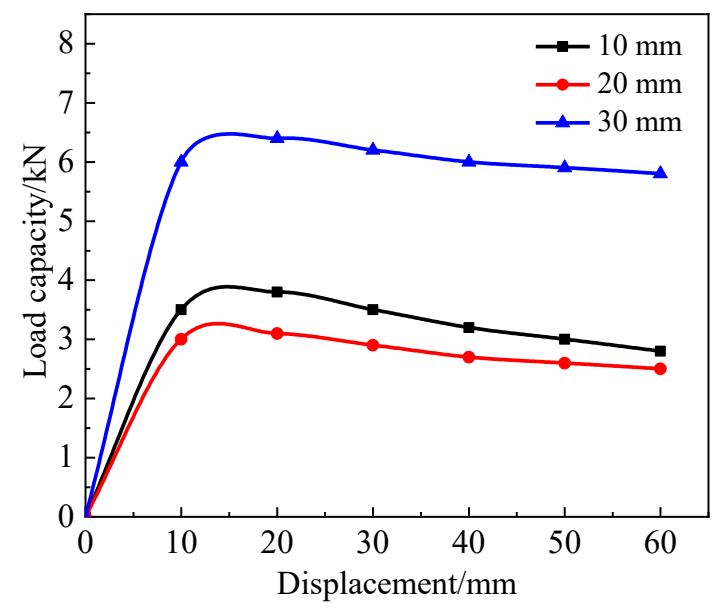

(a)

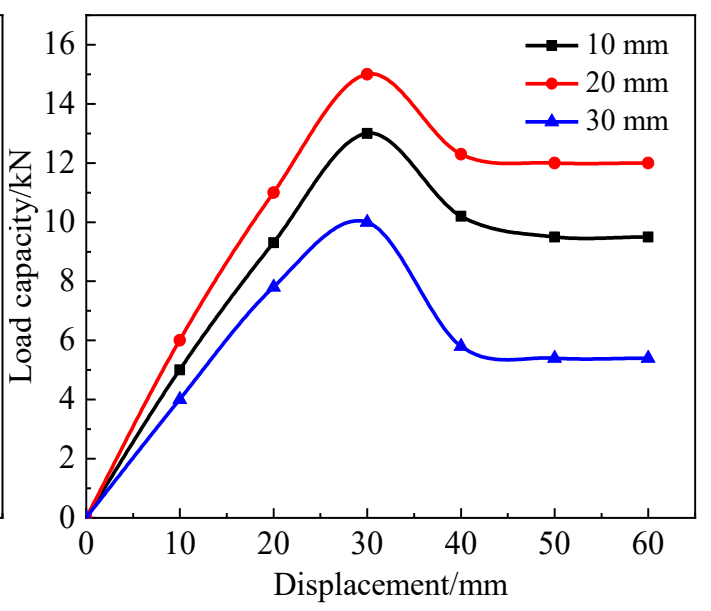

(b) 


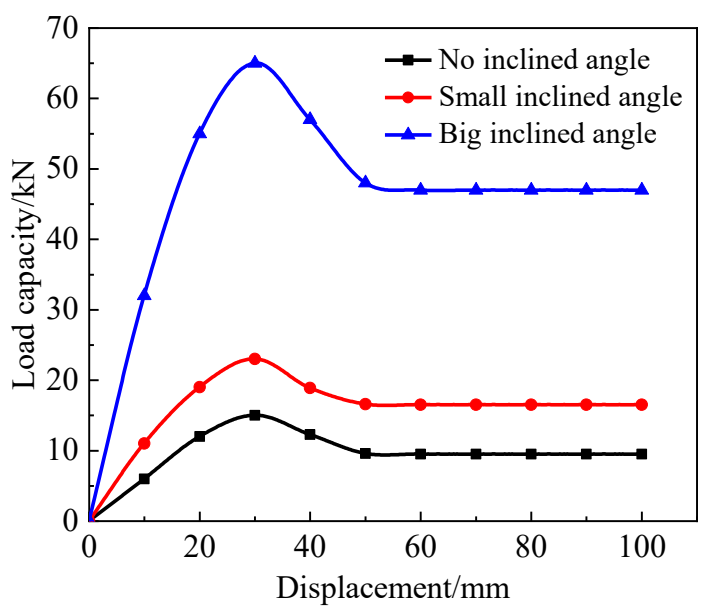

(c)

FIGURE 2. The load capacity-displacement curves of MYSP under different quantities of steel discs and different inclined angle of the outer tube at (a) 6 pieces of steel discs and $0^{\circ}$ of inclined angle; (b) 19 pieces of steel discs and $0^{\circ}$ of inclined angle; (c) 19 pieces and $20 \mathrm{~mm}$ length of steel discs

The load capacity of MYSP must meet the requirement of mine safety production. However, it still cannot provide enough load capacity by the increase of the quantities of steel discs or by the increase of inclined angle of the outer tube. This is mainly because that the increment of steel discs only increases the friction between the steel discs and the outer tube and inner tube. The load capacity is affected by the installation effect easily, while the steel balls can be embedded into the pole under high pressure. Therefore, the steel balls can be used instead of steel discs to test the load capacity.

\section{INFLUENCE OF THE DIAMETERS AND LAYER NUMBER OF STEEL BALLS ON LOAD CAPACITY}

Figure 3 shows the load capacity and displacement curves of different diameters and layer number of steel balls. From Figure 3(a) and 3(b), it is observed that when the diameter of steel balls is $4.00,4.40$, and $4.83 \mathrm{~mm}$ with single-layer low-hardness steel balls, the maximum load capacity is 26,70 , and $109 \mathrm{kN}$. while the respective maximum load capacity is 37,142 , and $120 \mathrm{kN}$ with double-layer steel balls. The maximum load capacity increases by $42.3,74.3$, and $10.1 \%$, but the stable load capacity increases gradually with the increase of diameters of steel balls. Therefore, select the diameter of steel balls as $4.83 \mathrm{~mm}$ under the consideration of the placement of double-layer steel balls.

The load capacity of MYSP is closely related to single steel ball and the quantities of steel balls (Chen et al. 2016). For single-layer low-hardness steel balls with same material properties, the load capacity- displacement curves under different diameters of steel balls cross each other in $d=13 \mathrm{~mm}$, but the load capacity decreases gradually with the increase of the diameter of steel balls in $0<d<13 \mathrm{~mm}$. This is mainly because that large quantities of steel balls embedded in the MYSP results in a large total area and high load capacity at the initial loading when the diameter of steel balls is small. Similarly, the steel balls embedded in the MYSP results in a small total area and low load capacity when the diameter of steel balls is large. However, with the shrinking down of the pole, the embedded area has basically reached the maximum in small diameter of steel balls, while it increases accumulatively and reaches or even exceeds that with small diameter $(d \geq 13 \mathrm{~mm})$ of steel balls gradually in large diameter of steel balls. Therefore, the load capacity increases gradually with the increase of the diameters of steel balls at this stage.

For double-layer low-hardness steel balls, the load capacity increases gradually with the increase of the diameter of steel balls at the initial loading, and the maximum load capacity with $4.83 \mathrm{~mm}$ steel balls is less than that with $4.40 \mathrm{~mm}$ steel balls. This is mainly because that when the diameter of steel balls is large, the first layer steel balls embeds in the MYSP deeply resulting in much plastic deformation of the pole, while the second layer steel balls slides along the trajectory of the first layer steel balls resulting in small cutting area of the pole and low load capacity. When the diameter of steel balls is small, it results in a little plastic deformation of the pole and part deformation reversion, and causes large cutting area of the pole, and still can provide a certain degree of load capacity. 
The supporting stiffness and load capacity of MYSP are improved with the increase of the layer number of steel balls. Figure 3(c) and Figure 3(d) shows that the maximum load capacity increases from 70 to $142 \mathrm{kN}$ when either single-layer or double-layer low-hardness steel balls with $4.4 \mathrm{~mm}$ were for the tests. The stable load capacity is $80 \mathrm{kN}$ under double-layer conditions and $40 \mathrm{kN}$ under single-layer conditions. As a result, the support stiffness increases from 2.33 to $2.84 \mathrm{kN} \mathrm{mm}^{-1}$. The maximum load capacity, the stable load capacity and the support stiffness increase by $102.9,55.0$, and $21.9 \%$, respectively. However, the respective maximum load capacity for single-layer and double-layer low hardness steel balls with $4.83 \mathrm{~mm}$ are 108 and $120 \mathrm{kN}$. The stable load capacity is $91.2 \mathrm{kN}$ under double-layer conditions and $43.2 \mathrm{kN}$ under single-layer conditions. Thus, the support stiffness increases from $2.70 \mathrm{~N}$ to $4.00 \mathrm{kN} \mathrm{mm}^{-1}$. The maximum load capacity, the stable load capacity and the support stiffness increased by $11.1,111.1$ and $48.1 \%$, respectively. Therefore, the double-layer steel balls forming as the bead frame was selected after considered its large stable load capacity and the influence of the diameter of steel balls on load capacity.

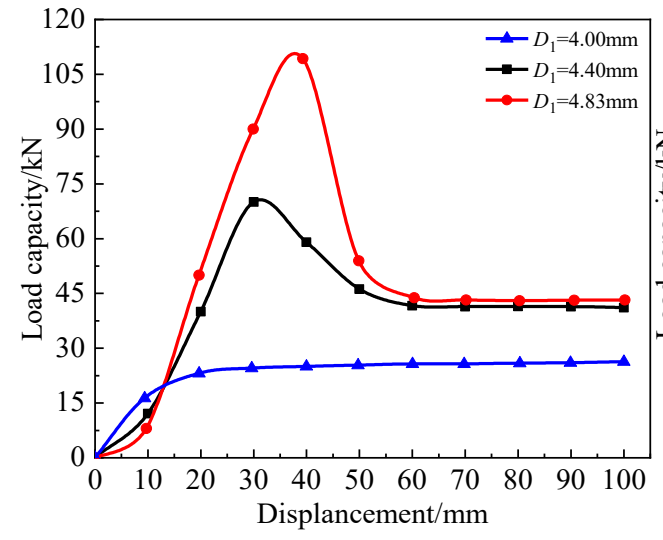

(a)

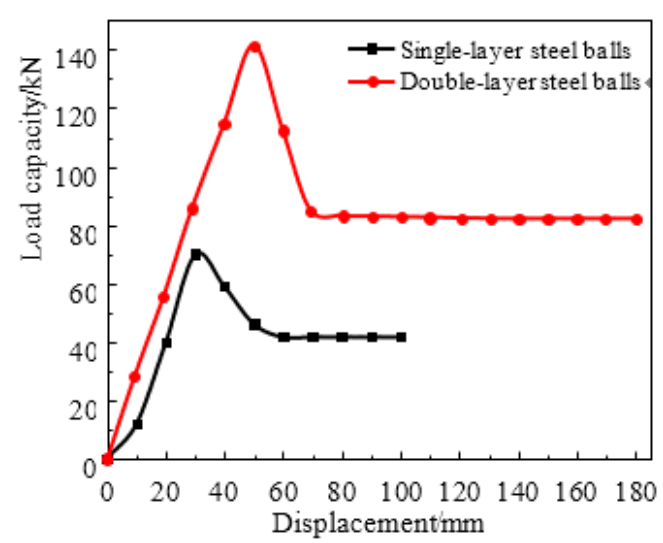

(c)

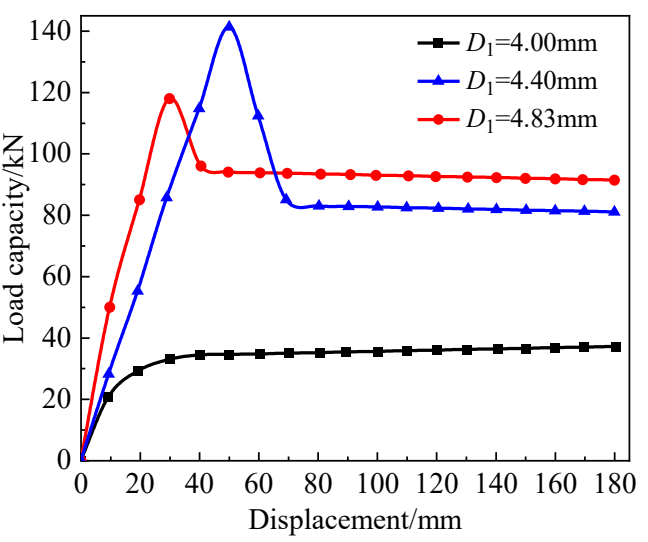

(b)

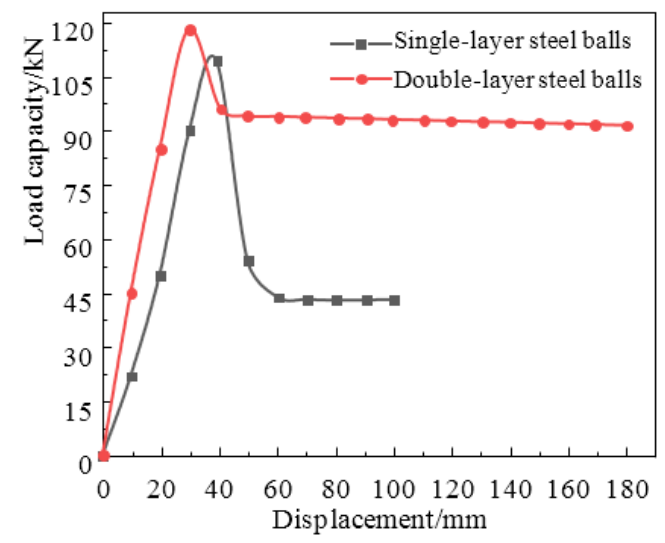

(d)

FIGURE 3. The diameters and layer number of steel balls (a) single-layer steel balls; (b) double-layer steel balls; (c) the layer number of steel balls with $4.40 \mathrm{~mm}$; (d) the layer number of steel balls with $4.83 \mathrm{~mm}$

INFLUENCE OF THE INCLINED ANGLE OF THE OUTER TUBE AND THE MATERIALS OF STEEL BALLS ON LOAD CAPACITY

Figure 4 shows the load capacity-displacement curves of the impact of the inclined angle of the outer tube on load capacity. It can be found from Figure 4(a) that when double-layer low-hardness steel balls are adopted, the load capacity firstly increases and then decreases and finally remains unchanged with the increase of displacement. 
However, there's a slight difference in different inclined angle. Divide any load capacity by each maximum load capacity as load capacity ratios, and the ratio curve of displacement between 30 and $70 \mathrm{~mm}$ is shown in Figure 4(b). The maximum ratio value is 1 . It is clearly seen from the figure that the stable load capacity accounts for $94.4,88.0,78.0$, and $55.6 \%$ of the maximum value, respectively, with the increase of the inclined angle. The larger the inclined angle is, the larger attenuation ratio is when it reaches after the maximum load capacity.

When double-layer high-hardness steel balls are adopted as shown in Figure 4(c), at the beginning, the load capacity increases and then remains unchanged with the increase of displacement. The stable load capacity with the inclined angle of $3.81,4.57,5.71$, and $7.13^{\circ}$ are 360 , 340,330 , and $315 \mathrm{kN}$, respectively, which increased by $111.8,157.6,258.7$, and 530.0\% compared with double- layer low-hardness steel balls (whose value is 170, 132, 92 , and $50 \mathrm{kN}$, respectively). But the load capacity does not vary greatly under different inclined angles of the outer tube. Therefore, it is very effective to improve the load capacity by using double-layer high-hardness steel balls. However, the influence degree of the inclined angle of the outer tube on load capacity is smaller than that with double-layer low-hardness steel balls under this condition. Figure 4(d) shows the relationships of the maximum and the stable load capacity with low-hardness and high-hardness steel balls with inclined angle of the outer tube. The slope of the curve with double-layer lowhardness steel balls is higher than that with double-layer high-hardness steel balls. the inclined angle of the outer tube has a huge influence on load capacity with doublelayer low-hardness steel balls.

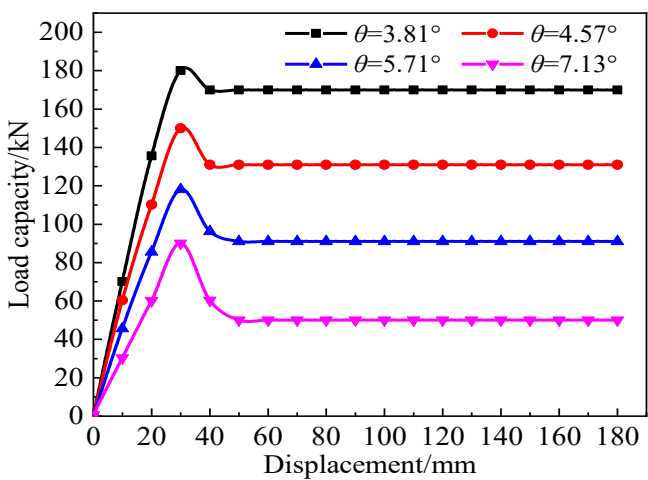

(a)

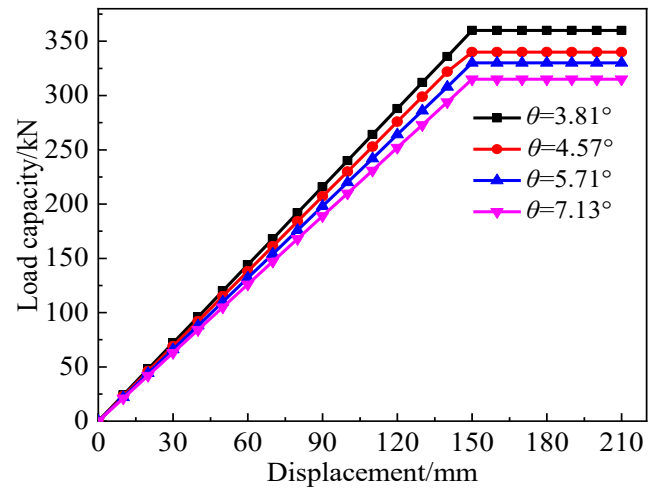

(c)

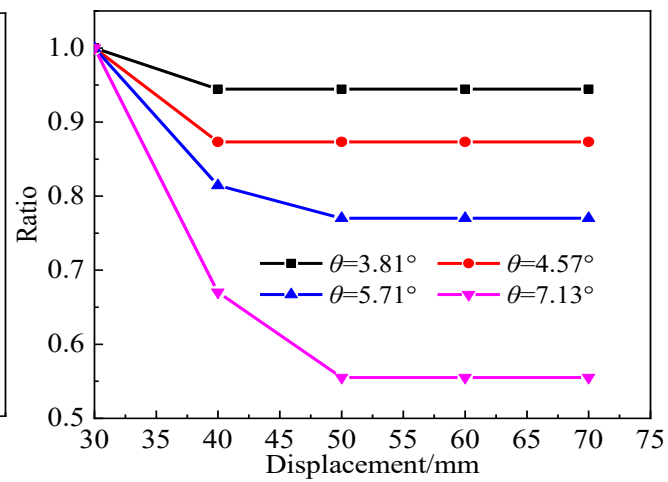

(b)

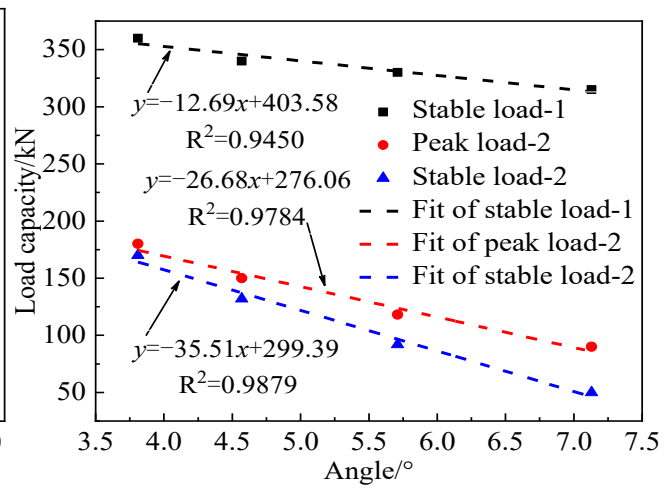

(d)

FIGURE 4. The load capacity-displacement curves with different inclined angles of the outer tube and different materials of steel balls (a) the load capacity-displacement curves with low-hardness steel balls; (b) comparison of the maximum load capacity with lowhardness steel balls; (c) the load capacity-displacement curves with high-hardness steel balls; (d) curves of load capacity changing with the inclined angle of the outer tube 


\section{INFLUENCE OF THE MATERIAL OF THE POLE ON LOAD CAPACITY}

It can be found that the adoption of double-layer highhardness steel balls can improve the load capacity significantly through the above test results. However, the influence of the inclined angle of the outer tube on its load capacity is low under this condition. The load capacitydisplacement curves with different yielding strengths versus the material of the pole are shown in Figure 5. It can be seen from Figure 5(a) and 5(b) that the load capacity increases with the increase of yielding strength. The yielding strength increases from $235 \mathrm{MPa}$ (when the load capacity is $414 \mathrm{kN}$ ) to 345,690 , and $835 \mathrm{MPa}$, while the load capacity increases by 30,50 , and $100 \mathrm{kN}$, with the growth rates of $7.2,12.1$, and $24.2 \%$, respectively. Therefore, the MYSP with different load capacities can be designed by changing the yielding strength of the outer tube and inner tube. The tested load capacity value with double-layer high-hardness steel balls is much higher than that with steel discs and low-hardness steel balls.

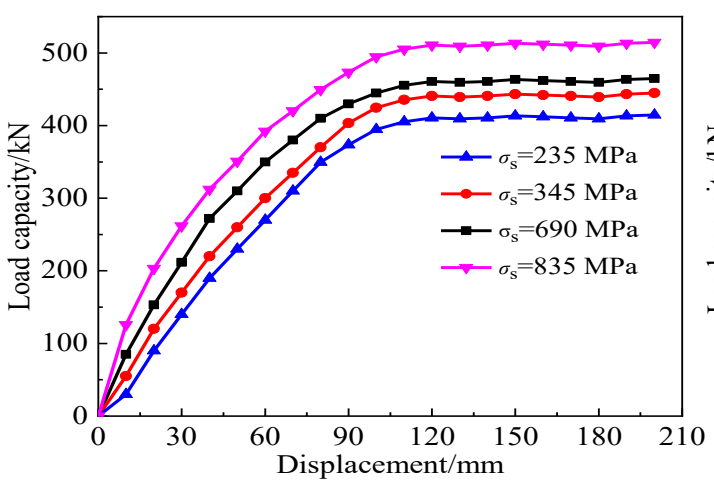

(a)

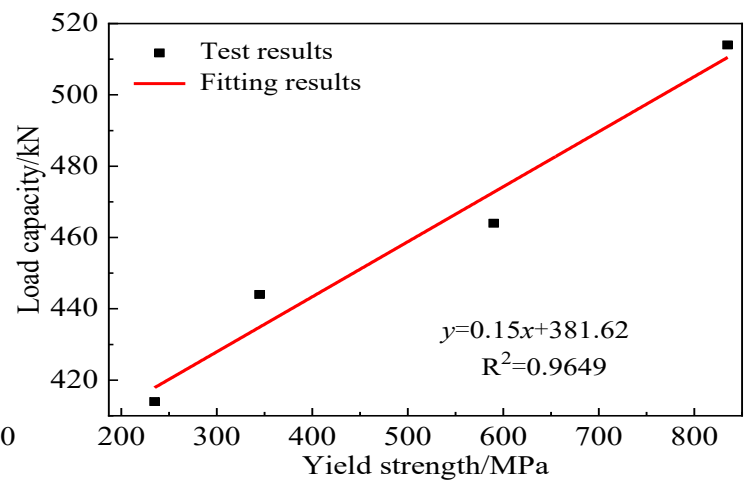

(b)

FIGURE 5. The influence of the material of the pole on load capacity (a) the load capacitydisplacement curves with different materials of the pole; (b) the curves of load capacity changing with the yielding strength of the pole

\section{ENGINEERING APPLICATION}

\section{Engineering background}

In order to evaluate the support effect of the MYSP, a field test was carried out on the 8218 working face of a coal mine. Low level caving technology was adopted for ultra-thick seam in 8218 working face. The thickness of coal seam is more than $15 \mathrm{~m}$, and the coal seam is loose and easy to be broken. More than 10 meters' thickness of coal seam is located above the roof of mining roadway. The support was poor because it was affected by the preabutment pressure from the mining working face and the conditions of roof was difficult to be supported using anchor net cables. The wood cribs were erected on one side of the mining roadway for support improvement based on the original support scheme. However, because of the excessive consumption of timber crib support, the cost of support was high, and the operation process was complicated. This wooden support reduces working space of transportation tunnel and lead to non-ideal effect. Therefore, the main task here is to maintain the stability of mining roadway in the safer way.

\section{Support scheme design}

An experimental study on the MYSP in pre-support of mining roadway was carried out for this engineering task. The width of roadway is $5000 \mathrm{~mm}$, and the support height is $4000 \mathrm{~mm}$. With the consideration on pressure of the loose circle of the overlying strata and the specific engineering geological conditions of this coal mine, the load capacity proposed for the roadway is $500 \mathrm{kN}$. In order to ensure that ventilation, pedestrians and transportation were not disturbed, a row of MYSPs are arranged in the center of the roadway, with a spacing of $1600 \mathrm{~mm}$. The bolt and anchor cable on the roof are connected by $\mathrm{W}$-steel belt to increase the contact area. In addition, the rhombic metal mesh was used to protect mining roadway from falling broken rock from the roof, as shown in Figure 6(a).

\section{Support effect evaluation}

The $450 \mathrm{~m}$ mining roadway of the working face was divided into three sections. Each section was $150 \mathrm{~m}$ long and was supported with the original support test, 
timber crib support and MYSP support, respectively. The deformation of surrounding rock and the stress condition of timber crib and MYSP in this three sections were monitored.

The monitoring points are located in the middle of each section. The changes of the roof-to-floor convergence of roadway were measured for every $10 \mathrm{~m}$ the working face. It can be found from Figure 6(b) and Figure 6(c) that the roof-to-floor convergence increases gradually with the increase of the forward distance, but its growth rate shows a change trend of increase at the beginning and then decrease. The maximum roof-tofloor convergence is 548, 397, and $224 \mathrm{~mm}$, respectively, under the support conditions of this three sections, which reduces by 26.8 and $59.1 \%$ in the timbering support and the MYSP support compared with the original support. Therefore, it is significant to reduce the deformation of roadway surrounding rock by using MYSP as presupport.

The largest deformation rate of the surrounding rock is located at $60 \mathrm{~m}$ from the working face. Deformation comparisons between the timbering and the MYSP can be observed from Figure 6(d). Some timbers were fractured due to its load capacity reduced, but the MYSPs high constant resistance and stability characteristics. Therefore, by using the MYSP to support the mining roadway, the stability of roadway surrounding rock is maintained and the support cost is greatly reduced, which is about $60 \%$ lower than that of the timbering support.

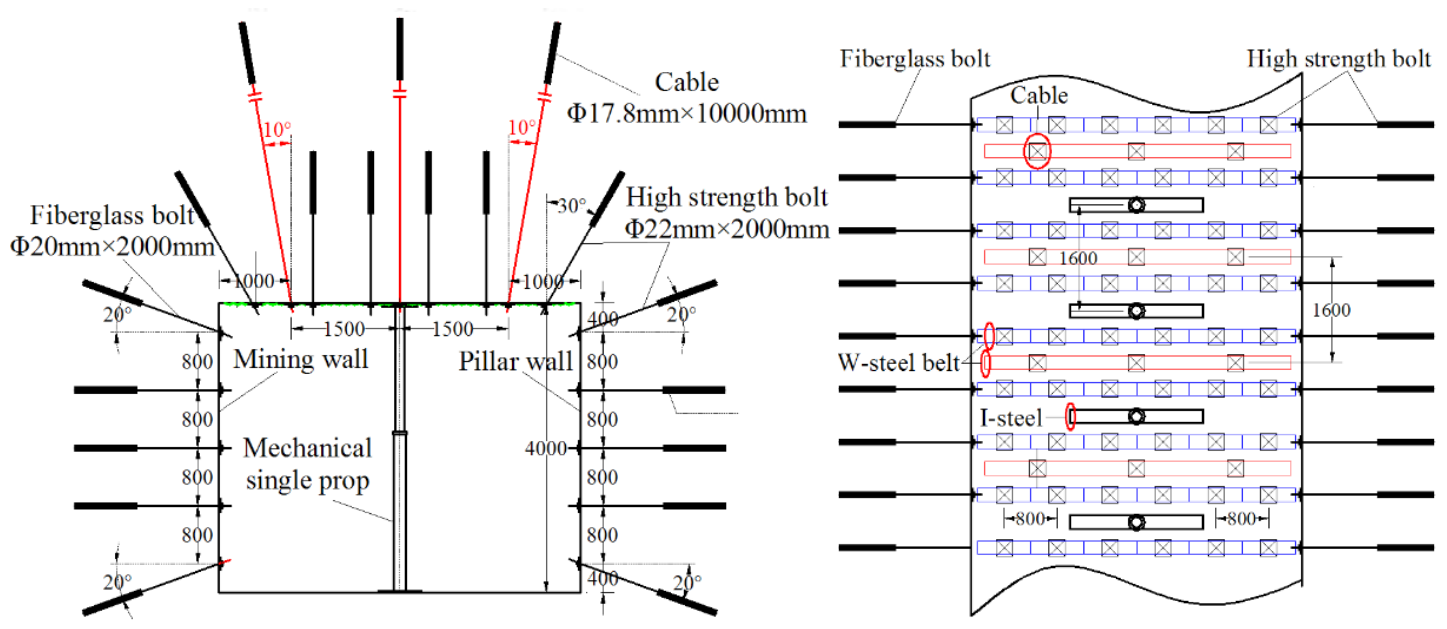

(a)

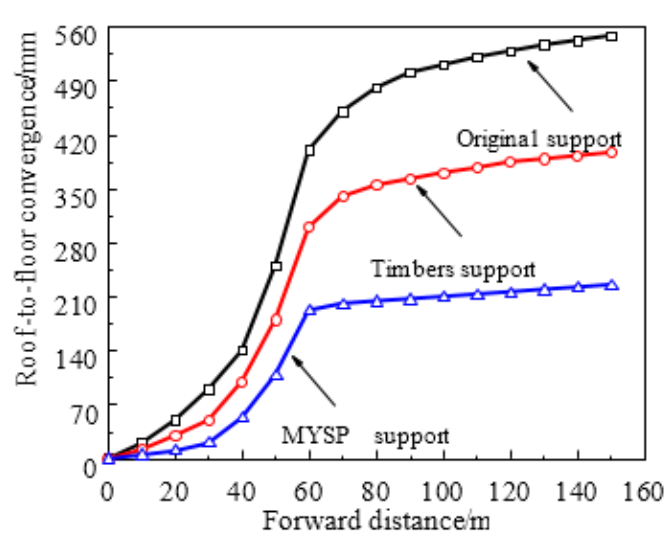

(b)

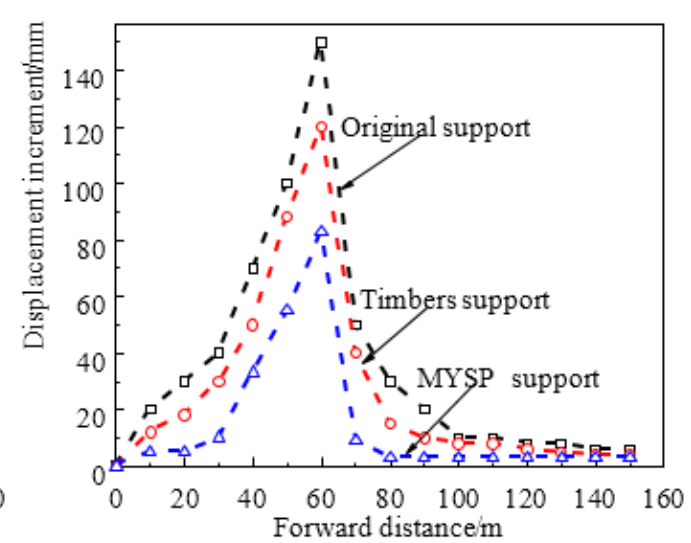

(c) 


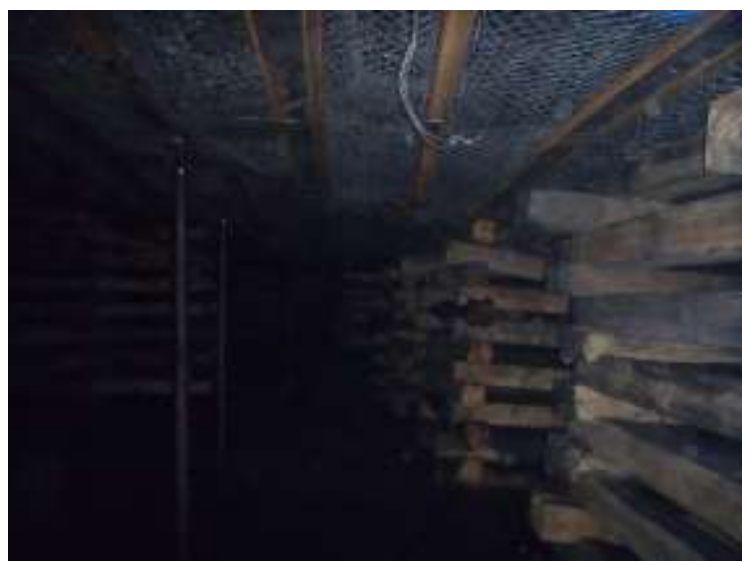

(d)

FIGURE 6. Engineering application of the MYSP (a) the cross-section diagram and the plane graph of supporting; (b) the roof-to-floor convergence; (c) the growth rate of roof-to-floor convergence; (d) deformation comparisons between the timber crib support and the MYSP support

\section{CONCLUSION}

In this paper, the effects of the layer number of steel discs, the diameters and the layer number of steel balls, the inclined angle of the outer tube, the materials of steel balls and the pole on load capacity were investigated, which has optimized the load capacity of the MYSP and also been successfully applied to the mining roadway. At the same time, the deformation of roadway surrounding rock was controlled and the supporting cost was reduced. The main conclusions are as summarized.

When the steel discs are used as the friction mediums, the load capacity with $20 \mathrm{~mm}$ length and 19 pieces of steel discs is $15 \mathrm{kN}$, and can be increased effectively by increasing the inclined angle of the outer tube. When the steel balls are used as the friction mediums, the load capacity provided by steel balls is higher than that provided by steel discs. the load capacity provided by double-layer steel balls is higher than singlelayer steel balls. The maximum load capacity can be up to $120 \mathrm{kN}$ when the diameter of double-layer steel balls is $4.83 \mathrm{~mm}$. The load capacity provided by high-hardness steel balls is higher than that provided by low-hardness steel balls. The load capacity decreases with the increase of inclined angle of the outer tube. However, the inclined angle of the outer tube has a small influence on load capacity provided by high-hardness steel balls. To the low-hardness steel balls, the larger the inclined angle is, the larger attenuation ratio is when it reaches after the maximum load capacity. The load capacity increases gradually with the increase of the yielding strength of the pole. When the yielding strength is up to $835 \mathrm{MPa}$, the load capacity can be up to $514 \mathrm{kN}$. The MYSP with different load capacities can be designed by changing the yield strength of the outer tube and inner tube. The field application shows that the MYSP has good characteristics of yielding and high constant resistance. The maximum roof-to-floor convergence is just $224 \mathrm{~mm}$ by using MYSP as pre-support, which reduces by $59.1 \%$ compared with the original support. The deformation of surrounding rock is controlled effectively, and the supporting cost is reduced by $60 \%$.

\section{ACKNOWLEDGEMENTS}

This research was supported by the National Natural Science Foundation of China (51974295, U1803118). This publication was also based on work supported by Universiti Kebangsaan Malaysia internal grant GUP2018-116.

\section{REFERENCES}

Chen, S.Z., Goh, T.L., Han, L. \& Gerson, S.V. 2019. Effects of tectonic stresses and structural planes on slope deformation and stability at the Buzhaoba open pit mine, China. Sains Malaysiana 48(2): 317-324.

Chen, X.X., Du, B.J., Wang, L.C. \& Fu, D.H. 2016. Control mechanism and application of large deformation of dynamic pressure roadway of fully mechanized top-coal caving face. Chinese Journal of Geotechnical Engineering 38(3): 460-467.

Chen, Y.L., Hao, Y., Wu, Y., Zhang, K. \& Zhang, G.M. 2017. The load capacity model and experimental tests of a new 
yielding steel prop. Mathematical Problems in Engineering 2017(2017): 1-11.

Chen, Y.L., Yu, B.Y, Zhang, K., Zhang, M.W., Xu, G. \& Chen, Z.Q. 2018. Permeability evolution and particle size distribution of saturated crushed sandstone under compression. Geofluids 2018(2018): 1-12.

González-Nicieza, C., Menéndez-Díaz, A., Álvarez-Vigil, A.E. \& Álvarez-Fernández, M.I. 2008. Analysis of support by hydraulic props in a long wall working. International Journal of Coal Geology 74(1): 67-92.

Hao, Y., Wu, Y., Chen, Y.L. \& Teng, Y. 2019. An innovative yielding prop with high stable load capacity and long shrinkage distance in coal mine. Mechanics of Advanced Materials and Structures 26(18): 1568-1579.

Kang, H. 2014. Support technologies for deep and complex roadways in underground coal mines: A review. International Journal of Coal Science \& Technology 1(3): 261-277.

Peng, W.Q., Wang, W.J. \& Yuan, C. 2018. Supporting technology research in deep well based on modified Terzaghi formula. Advances in Civil Engineering 2018(2018): 1-6.

Qin, D., Wang, X., Zhang, D. \& Chen, X. 2019. Study on surrounding rock-bearing structure and associated control mechanism of deep soft rock roadway under dynamic pressure. Sustainability 11(7): 1892-1907.

Qin, L. 1995. Analysis of support condition of metal friction strut. Safety in Coal Mines 7: 24-25

Tang, J.X., Wang, Y.L., Xu, G.J., Dai, Z.Y. \& Liu, M. 2018. Mechanism and control of failure for surrounding rock in highly stressed 'three soft' coal seam mining roadway. Journal of Mining \& Safety Engineering 35(3): 449-456.

Wang, L.F., Chang, Z.C., Yang, Z.B., Wang, X.F. \& Qin, D.D. 2018. Combined support technology of roadway under mined gob of ultra-distance seams in deep mine. Journal of Mining \& Safety Engineering 35(4): 686-692.

Wang, W.J., Yuan, C., Yu, W.J., Wu, H., Peng, W.Q., Peng, G., Liu, X.S. \& Dong, E.Y. 2016. Stability control method of surrounding rock in deep roadway with large deformation. Journal of China Coal Society 41(12): 2921-2931.

Wang, X., Qin, Q. \& Fan, C. 2017. Failure characteristic and fracture evolution law of overburden of thick coal in fully mechanized sub-level caving mining. Sains Malaysiana 46(11): 2041-2048.

Wang, X., Yang, Z., Feng, J. \& Liu, H. 2013. Stress analysis and stability analysis on doubly-telescopic prop of hydraulic support. Engineering Failure Analysis 32: 274-282.

Wu, G., Jia, S., Chen, W., Yuan, J., Yu, H. \& Zhao, W. 2018. An anchorage experimental study on supporting a roadway in steeply inclined geological formations. Tunnelling and Underground Space Technology 82: 125-134.

Yang, S.Q., Chen, M., Jing, H.W., Chen, K.F. \& Meng, B. 2017. A case study on large deformation failure mechanism of deep soft rock roadway in Xin'An coal mine, China. Engineering Geology 217: 89-101.
Yang, X., Hu, C., He, M., Wang, H., Zhou, Y., Liu, X., Zhen, E. \& Ma, X. 2019. Study on presplitting blasting the roof strata of adjacent roadway to control roadway deformation. Shock and Vibration 2019: 1-16.

Zhang, J., Liu, L., Shao, J. \& Li, Q. 2019. Mechanical properties and application of right-hand rolling-thread steel bolt in deep and high-stress roadway. Metals 9(3): 346-364.

Zhang, Q., Zhang, J., Tai, Y., Fang, K. \& Yin, W. 2015. Horizontal roof gap of backfill hydraulic support. Journal of Central South University 22(9): 3544-3555.

Zhang, S., Lu, P. \& Wang, H. 2019. Numerical simulation analysis of unsteady temperature in thermal insulation supporting roadway. Mathematical Problems in Engineering 2019(2019): 1-8.

Zuo, J.P., Wen, J.H., Hu, S.Y. \& Zhao, S.K. 2018. Theoretical model and simulation study of uniform strength beam support in deep coal mine roadway. Journal of China Coal Society 43(1): 1-11.

Yanlong Chen, Hai Pu, Peng $\mathrm{Wu}^{*}$, Haoshuai Wu, Yu Wu \& Yang Hao

State key Laboratory for Geomechanics \& Deep Underground

Engineering

University of Mining and Technology

Xuzhou 221116

China

Hai $\mathrm{Pu}$

College of Mining Engineering and Geology

Xinjiang Institute of Engineering

Urumqi, Xinjiang, 830091

China

Goh Thian Lai \& Azrin Azmi

Centre for Earth Science and Environment

Faculty of Science and Technology

Universiti Kebangsaan Malaysia

43600 UKM Bangi, Selangor Darul Ehsan

Malaysia

Muslim Abdurrahman

Department of Petroleum Engineering

Universitas Islam Riau

Pekan Baru, 28284

Indonesia

*Corresponding author; email: pengw@cumt.edu.cn

Received: 20 September 2019

Accepted: 8 March 2020 